which succeed it at Eycott Hill. Analyses of the latter, quoted by Mr. Ward in the paper mentioned above, show the silica percentages of three of them to be respectively $53 \cdot 3,52 \cdot 6$ and $51 \cdot 1$. The Falcon Crag rocks are shown by $\mathbf{M r}$. Wurd (though he coined for them the unhappy term felsidolerite) to be in reality andesites, which microscopically and chemically ${ }^{\prime}$ present only such differences from the inodern representatives of that group as we should naturally expect in rocks of such great antiquity. By the kindness of Prof. A. W. Williamson, the silica percentage of the red variety of the Eycott Hill rock has been determined for me by Mr. T. Cooksey in the laboratory of University College. He finds it to be 53.06 (one determination giving 53.40 another $52 \cdot 73)^{2}$ with a specific gravity of $2 \cdot 754$. The rock must therefore remain among the basalts (the glassy condition of its base renders the name dolerite inappropriate). It belongs, however, to the side of the basalt group which is the richer in silica, and is nearly represented among modern rocks by some of the basalts of the Inner Hebrides in Prof. Judd's collection. It also resembles in certain respects some of the magma basalts described by Boricky (Petrographische Studien an den Basaltgesteinen Böhmens). The amount of alteration may justify us in naming it now an enstatite-diabase, but I feel no doubt that it was originally. a true basalt rich in glass, containing a variety of enstatite.

\title{
I一
}

\section{Dr. Fritsch's Permian Amphibians of Bohemia.}

DR. ANTON FRITSCH has now made such progress with his 1 Monograph on the Fauna of the Bohemian Permian rocks that we are able to recognize it as one of the most important and one of the ablest of molern contributions to Palæontology. For excellence of description it has not been surpassed; while from the minute dimensions of most of the Amphibian remains, care has been required in deciphering osteological characters, which bas resulted in a perfection of osteological labour. Specimens offering fewer difficulties might not perhaps have been studied with the same completeness. Professor Fritsch has shown that he is a learned comparative anatomist, whose wealth of knowledge has enabled him to enrich his pages with the fruits of many and varied studies, and to successfully interpret remains which are often obscure.

The third part of the work contains descriptions of Urocordylus scalaris, Keraterpeton crassum, Limnerpeton modestum, L. laticeps, L. macrolepis, L. elegans, L. obtusatum L. dubium, L. difficile, and a note on $L$. caducum. Like the foregoing part it consists of 32 quarto pages of text, well illustrated by many excellent figures printed with the text; and by 12 coloured plates.

The memoir begins with some account of the family Nectridea,

1 Two analyses of lavas from the Keswick district giren in the Survey Memoir give silica percentages of $60 \cdot 718$ and $59 \cdot 5$ I $\downarrow$ respectively.

2 IIe also writes, "The rock contains a small amount of calcium, less magnesium, but mainly iron, aluminium and silica." 
which are long-tailed lizard-like animals, usually with elongated epiotic horns, and tail vertebræ devoid of ribs, but with the upper and lower spinous processes expanded in fan-like form. The genus Urocordylus, which was established by Huxley and Wright, has the head triangular, blunt in front, and truncated behind, with the cranial bones covered with round pits, which suggest those on the skulls of crocodiles. The strong tail includes about 80 vertebra. 'The strong ribs are double-headed, and about three times as long as the vertebre.

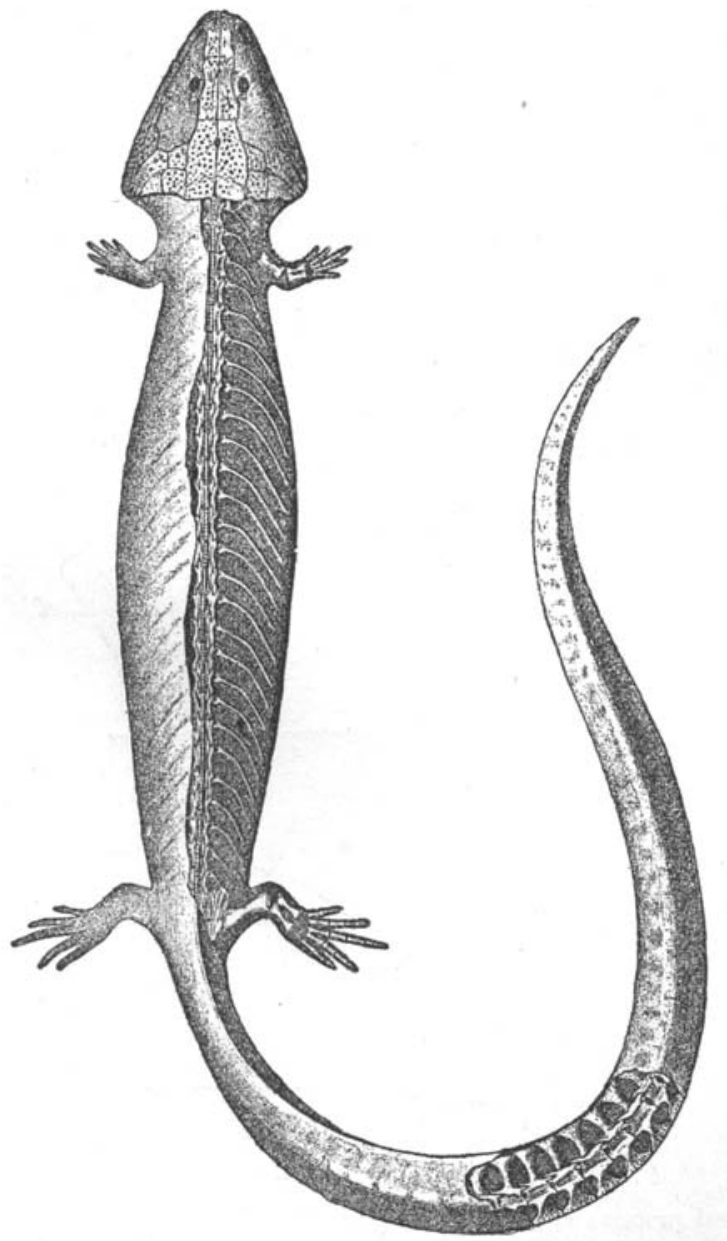

Fig. I.-Restoration of Vrocordylus scalaris (Fritsch).

The thin shield-shaped thoracic plate is expanded in front. The lateral thoracic plates are broad and spoon-shaped. The abdominal scales are smooth and elliptical. The feet are five-toed; the hinder limbs are longest. The Urocordylus scalaris of Fritsch is distinJECADE III.-VOL. II.-NO. II. 


\section{Reviews-Dr. Fritsch's Permian Amphibia of Bohemia.}

guished from the $U$. Wandesfordii of Huxley by having broader spinous processes to the caudal vertebræ, but the distinction is not of a striking kind; and the remains are imperfectly preserved. The restoration is founded partly upon the Bohemian fragments, partly upon Irish specimens. The head is one-fourth of the length of the body, and the body is about one-half the length of the tail. From the proportions of the body and limbs, the animal is presumed to have been essentially aquatic, and from the well-developed abdominal armonr is inferred to have crawled along the bottom. There are no indications of scutes on the upper side of the body or on the tail. The abdominal armour consists of more than 100 rows of somewhate elongated scutes, which vary in size and form. They commence behind the thoracic plate, and are arranged in oblique series of three or four on each side of the median line, overlapping on the inner side.

The form of the skull is more elongated than in Keraterpeton. The eyes were small, in the anterior half of the head, and separated from each other by three times the diameter of the orbits. There are eleven teeth on the palatine bone. The number of presacral vertebr» is unknown, but is estimated at 27 as compared with 20 in Urocordylus Wandesfordii. The vertebræ are strong and well ossified, and terminate in fan-shaped neural spines, which are

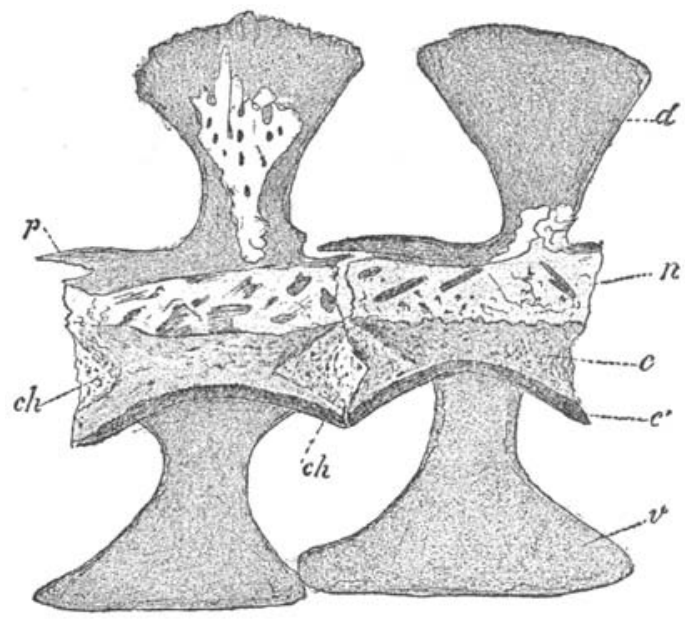

Fig. II.-Tail Vertebre entarged six times.

$d$, dorsal process; $v$, ventral process ; $p$, pre-zygapophysis; $c h$, notochord ; c, body of vertebra; $n$, neural canal.

serrated like a cock's comb. The specimens figured are from the first third of the tail, and show the dorsal and ventral processes. These caudal vertebra are compressed from side to side. Their number is unknown, but supposed to be about 80 , as in the Irish 
species. The ribs are hollow. In the anterior extremity only the sinall humerus has been recognized. The hind limbs were twice as strong as the fore limbs. There are no traces of gill arches.

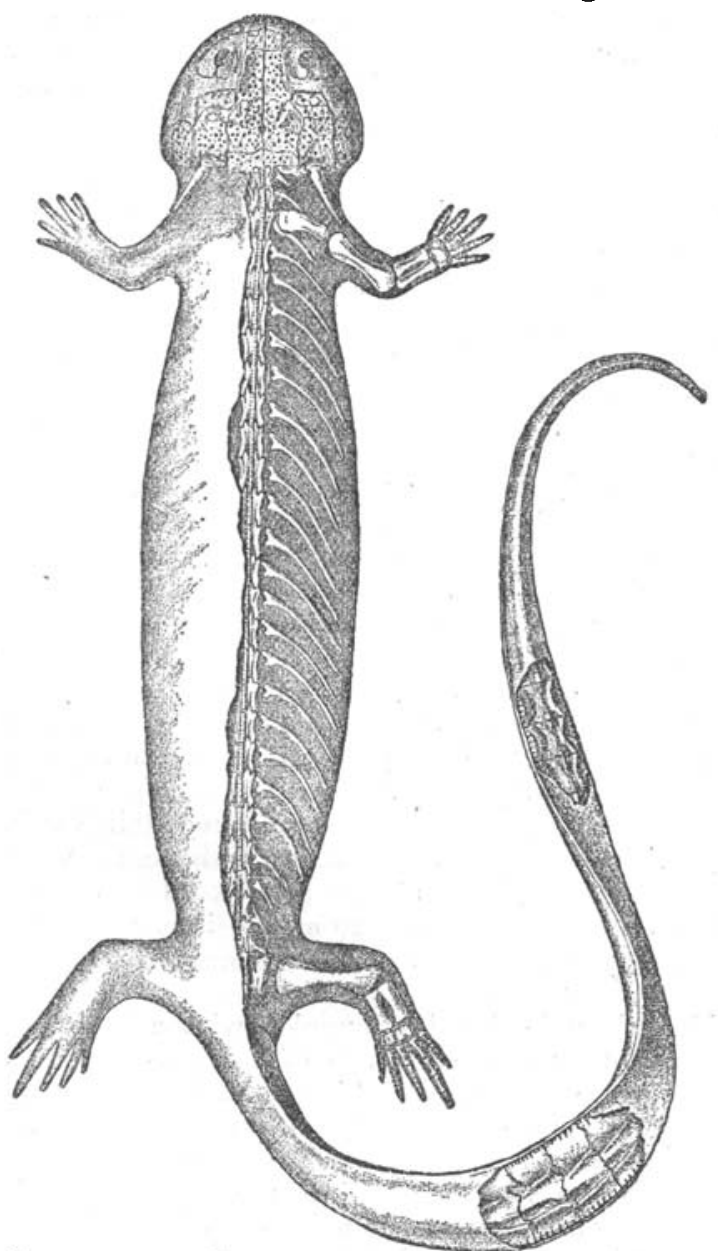

Fig. III.-Restoration of Keraterpeton crassum (K'ritsch); 1늘 times natural size.

A short account is given of the genus Keraterpeton, based upon Huxley's memoir, and then follows a description of the species K. crassum (Fr.). This is the only Bohemian species. It has the orbit of the eye small and placed well forward, and has a head smaller in proportion to the body than in the British species. It is known from three complete specimens and fragments of thirty others. The animal was much smaller than Urocordylus, but of a stronger build. The head has a wide frog-like form, with the characteristic epiotic spines (see Fig. 3). The body is five times as 
long as the head, and the tail more than twice as long as the body. The limbs have a development which sugrests locomotion by walking. and the small height of the processes of the caudal vertebra wonld indicate a comparatively bad swimmer. The skeleton is completely ossified, even the carpus and tarsus being here preserved. No indication of the skin is preserved, but there is a shield of strong armour which corers two-thirds of the width of the abdominal surface, and extends between the thoracic plates and the pelvis. This shield consists of more than forty rows of long rhomboid plates, directed obliquely backward from the median line, and has about eight keeled plates in each row. Each plate has four circular pits on its inner edge, which resemble the pits on the cranial bones. In the skull deep depressions in front of the nasal bones indicate the nares. The circular pits on the skull are absent from the inner part of the frontal bone. The premaxillary teeth, five on each side, are pointed, and constricted towards the base so as to have a spoon-shaped contour. There are about eleven or twelve teeth in the maxillary bone in one row. As the number of teeth indicates a small gape to the mouth, Professor Fritsch infers that Keraterpeton fed upon the small Crustacea and Myriapods which occur in the Bohemian coal. The epiotic horn, which is attached to the square epiotic bone, is wedge-shaped, and four times as long as the base is wide. Its length is half the length of the skull. Its under surface is furrowed. The orbit contains a circle of about twelve or fourteen sclerotic plates. No new light is thrown on the gills or hyoid arch; and it is probable, from the absence of gills, that they were lost early in life.

The number of the pre-sacral vertebræ is uncertain, but is believed to be about 23 ; they are similar in size and shape, and all carry ribs. The centrum is constricted in the middle. There are 40 caudal vertebræ. As in Urocordylus, there are no interspaces between the dorsal and ventral processes of these vertebræ. There are no caudal ribs.

The middle thoracic plate is triangular, with a $\mathrm{T}$-shaped elevated mass upon it like the interclavicle of Ichthyosaurus in form, with circular pits in the bone on each side of the median bar of the $T$. The lateral thoracic plate is formed of an oval shield with a short round curved stalk. It is pitted on the outer edge.

The fore-limb is shorter than in the Branchiosauridæ. The humerus bas the usual constriction in the middle, is widest at the distal end, and has an elevated ridge on the upper end. The bones of the fore-arm are half the length of the humerus. The number of carpal bones is unknown. The metacarpal bones and phalanges are short, so that the hand is shorter than the fore-arm. The terminal phalanges are blunt and conical. The hinder extremity is stronger, with digits which are relatively quite as short. The number of bones in the several digits is $1,2,3,2,1$.

The next family is named Limnerpetidæ. It is a group of Amphibians with broad frog-like head and long salamander-like body; and is armoured with sculptured scutes. The first species, Limnerpeton. 
modestum (Fritsch), is known from a lower jaw in which the bone is sculptured and the short conical teeth are of uniform size, which is $2 \frac{1}{2}$ times as long as wide. The second species, Limnerpeton laticeps (Fritsch), is $160 \mathrm{~mm}$. long, but badly preserved. It had the form of an Axolotl, and has been restored from a specimen found at Tremosna. There is no indication of the skin. Scale armour was developed on the ventral surface between the pectoral and pelvic regions, where there are 54 rows of short wide scutes, each row consisting of about 8 scutes. The scales were $4 \frac{1}{2}$ times as wide us long; they are marked with concentric lines, between which there are rows of minute punctures.

The skull is nearly as broad as long, rounded in front. The orbits are large and nearly circular. There were more than 40 small evensized teeth in the upper jaw, each half a millimetre in diameter, with with a large pulp-cavity. The epiotic bone is small and extends backwards into a short point. The squamosal bone is not divided as in Dawsonia and Melanerpeton. There are 24 presacral vertebræ bearing ribs. In the tail 22 caudal vertebræ can be counted, but there were probably 30 , and many of these vertebræ carry short ribs. The vertebræ are very deeply biconcave. Of the pectoral girdle, the only element known is the middle thoracic plate. The lateral thoracic plate or coracoid has a stalk-like process. The anterior extremities are strong, with the humerus nearly twice as long as the fore-arm, and the phalanges are short and slender; and the hind limb is similarly characterized.

The third species Limnerpeton macrolepis (Fr.), is characterized by quadrate scutes, one and a half times as wide as high, marked with longitudinal stria, and hav-

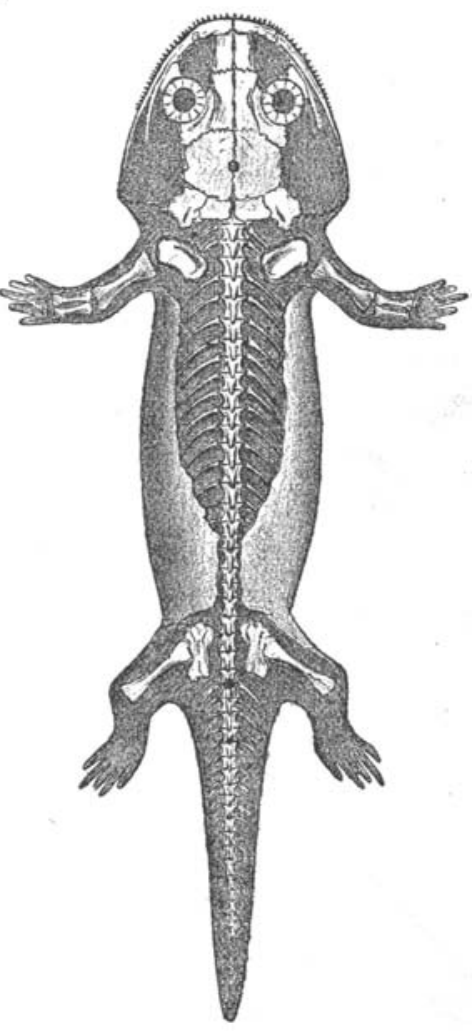

Fig. IV.-Restoration of Limnerpeton laticeps (Fritsch); natural size. ing the hinder edge thickened.

There are about twelve teeth in the premaxillary bone, distinguished by having their points furrowed. There are about forty bluntpointed teeth in the maxillary bone. There are more than forty teeth in the lower jaw. The form of the vomer is complicated. The middle thoracic plate is marked with radial striping. The vertebræ were slightly ossified and constructed on the amphiccelous 


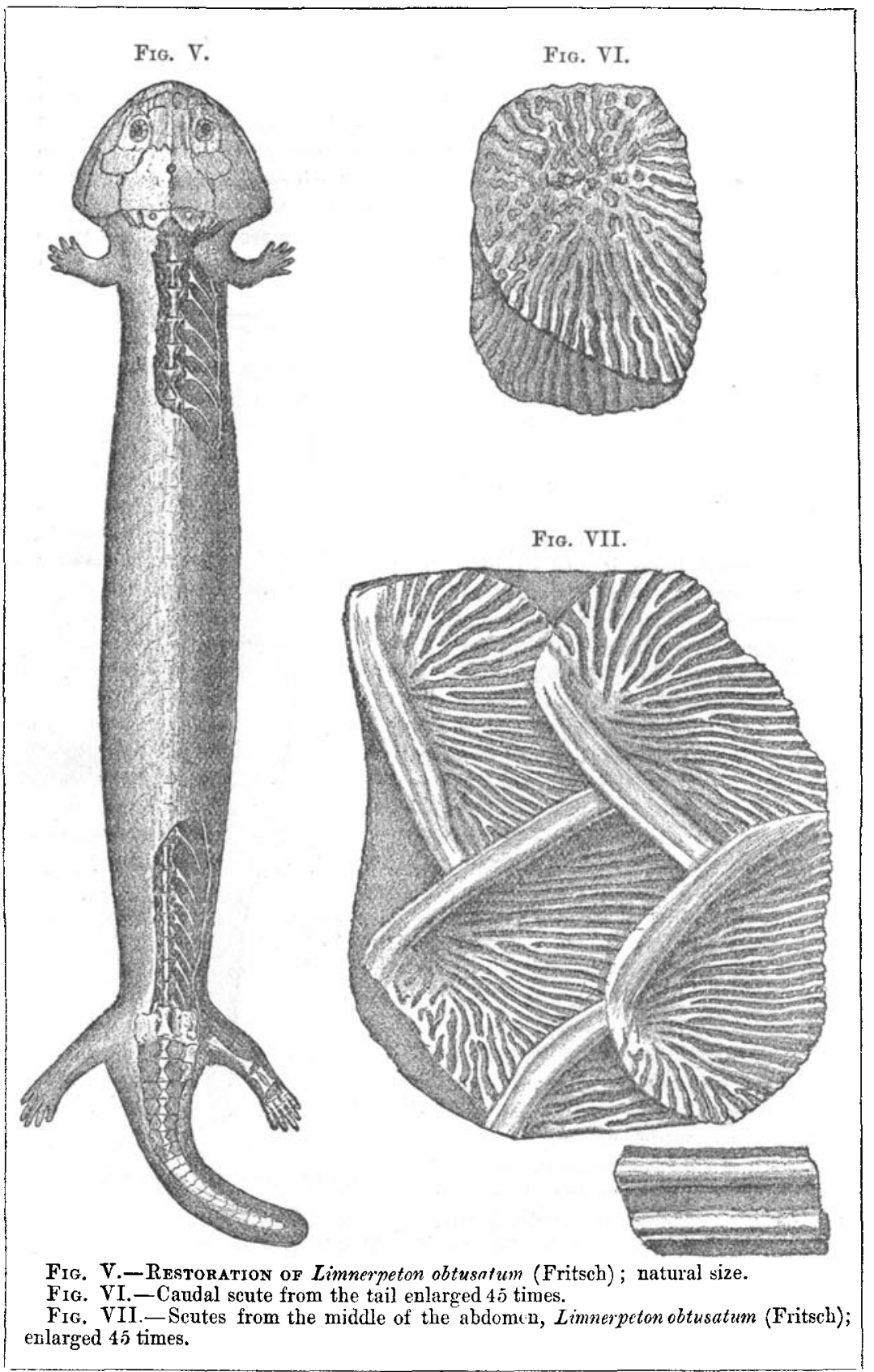


plan. The ribs are short with both ends expanded. The fourth species is Limnerpeton elegans (Fritsch). It has small oval scutes marked with cancellate marking which is partly concentric, partly diagonal. The remains are scattered. The skull-bones are comparatively smooth. They indicate a longer and smaller skull than that of the last species. The maxillary bone contains 23 teeth and may have included 35 teeth. 'The teeth are less regular in size than in other species of this genus. The shield of the parasphenoid bone is thickly toothed. The fifth species is Limnerpeton obtusatum (Fritsch). The scutes on the abdomen are of moderate size ornamented with ribs which branch at intervals, and have a thickened hinder edge. The scutes of the upper side of the body want the thickened edge.

The form of the body is greatly elongated, and the head is remarkably short and wide. The body is six times as long as the head, and the tail is twice as long as the head. The anterior extremity is much shorter than the hinder extremity. The abdominal armour consists of about 100 rows of scutes; each row contains six scutes on each side of the median line. Each scute is twice as broad as long. The skull is half as broad again as long. The orbits are in the anterior third of the skull, and are nearly double their diameter from each other. The teeth are small and smooth with pulp-cavities. The nasal bone is pitted. The epiotic bone is quadrate and ends in a process which is directed backward. The solerotic circle includes 12 bones. The hyoid in so far as it is preserved resembles that of Keraterpeton. There are about 37 presacral vertebræ, and about 16 in the tail, though 10 appear to be wanting. The notochord was continuous. The caudal vertebræ are very short and decrease rapidly in height. The dorsal ribs are $2 \frac{1}{2}$ times as long as the vertebræ, and have the capitulum and tuberculum most developed towards the neck. In the hinder extremity the phalanges are remarkably short.

Some other remains are described under the names Limnerpeton dubium, known only from a lower jaw ; L. difficile, known from a portion of a skull which is doubtfully referred to the genus; and $L$. caducum, founded upon a jaw and a rib.

Although many species have been described, it is impossible not to recognize that they are for the most part well characterized. And the publication of electrotypes of these perishable specimens will facilitate a comparison between some of the Bohemian species and their British allies, and thus demonstrate the nature of the affinity between them.

H. G. Seeley.

EEPORTS AND PROCEFDINGS.

Geological Societry of London.

T.-December 3, 1884 (Continued).-Prof. T. G. Bonney, D.Sc., LL.D., F.R.S., President, in the Chair. The following communication was read :-

3. "On the Lower Eocene Plant-bers of the Basaltic Formation of Ulster." By J. Starkie Gardner, Esq., F.G.S. 